\section{PP-225＼cjkstart経尿道的前立腺切除術における前立腺剥 離術の利用}

\section{諏訪赤十字病院泌尿器科 \\ 清河 英雄, 中山 剛}

【目的】前立腺肥大症に対し従来の前立腺切除術（TUR P）用装置を用いて前立腺剥離術を施行し,TUR - P にお ける有用性を検討した。【対象と方法】2008年 2 月より従 来のSTORZ 製 TUR システムを用い前立腺剥離術を施行 した 25 例（平均年齢 72 オ). $0^{\circ}$ のループ電極を下方に $45^{\circ}$ 傾け使用した。前立腺尖部 5 時 -7 時より凝固出力のみによ り剥離し,ループ電極にて切除した。【結果】前立腺尖部 5 時 -7 時より容易に腺腫を剥離できた。被膜穿孔は無かっ た.大きな腺腫では,初めに灌流液の通路を作る必要があっ たため，腺腫を 1 時,11 時より TURした，その後,残存腺 腫の剥離, 切除を施行した。平均切除重量 $36 \mathrm{~g}$ (4-95g), 平 均手術時間 105 分 (38-210 分), 平均 $\mathrm{Hb}$ 值は術前 $13.7 \mathrm{~g} / \mathrm{dl}$ $(11.2-15.7 \mathrm{~g} / \mathrm{dl})$, 術翌日 $12.2 \mathrm{~g} / \mathrm{dl}(9.0-14.8 \mathrm{~g} / \mathrm{dl}) .25$ 例中 7 例 は切除量 $50 \mathrm{~g}$ 以上で平均切除重量 $64 \mathrm{~g}$, 平均手術時間 131 分, 平均 $\mathrm{Hb}$ 值は術前 $14.5 \mathrm{~g} / \mathrm{dl}$, 術翌日 $12.8 \mathrm{~g} / \mathrm{dl}$ であった.カテー テル留置期間は平均 3.3 日 (3-6 日), 平均最大尿流率は術 前 $7.0 \mathrm{ml} / \mathrm{sec}(2-15 \mathrm{ml} / \mathrm{sec})$, 術後 $20.1 \mathrm{ml} / \mathrm{sec}(6-37 \mathrm{ml} / \mathrm{sec})$. 同種血輸血を要した例は無し、【結論】従来の TUR-P 用装 置を用いた凝固出力による前立腺剥離術は被膜穿孔するこ と無く容易であった，出血，低 $\mathrm{Na}$ 血症のコントロールに は被膜穿孔を起こさないことが重要であり, 従来からの慣 れた TUR-Pに凝固出力による前立腺剥離術を利用するこ とは有用であると考えられた

\section{PP-226}

TURis システムを用いた経尿道的前立 腺蒸散術「TURisV」の 1 年成績

\section{長久保病院泌尿器科}

大梘 英男, 桑原 勝孝, 塚本 拓司, 長久保一朗

【目的】TURis システムを用いた経尿道的前立腺蒸散術 「TURisV」は、侵襲度、手術手技、コストなどの面から 優れた手術法である。術後 1 年までの治療効果を検討し た。【対象】当院で TURisVを施行した 63 例を対象に、 排尿関連評価項目および合併症につき検討した。平均年 齢は 71.2 歳、IPSS 24.1、QOL score 5.2、Qmax 7.5ml/s、 PVR 142ml、Pvol $51.7 \mathrm{ml}$ であった。術後 1 か月（n=63）・ 3 か月 $(n=47) \cdot 6$ か月 $(n=37) \cdot 12$ か月 $(n=10)$ の時点 での各パラメータを測定した。【結果】平均手術時間は 61 分、カテーテル留置期間は 2.0 日、各パラメー夕の推移は、 IPSS 10.9、9.4、7.7、8.8、QOL score 2.7、2.4、2.0、2.2、 Qmax 14.8、14.5、17.1、14.1、PVR 32.0、33.0、31.9、 26.9、Pvol 34.5、28.1、29.2、24.0といずれも有意な改善 を認めた。合併症としては、後出血が $10.8 \%$ 、会陰部痛 $5.4 \%$ 、尿道狭窄 $8.1 \%$ 、一過性尿閉 4.1\%、尿路感染症 9.5\% であった。【考察】TURisVの利点としては、手技の習得 が容易、術中の出血が少ない、コストが比較的安いことな どが挙げられる。問題点としては、手術時間が比較的長い、 カテーテル抜去早期の排尿障害が比較的多い、後出血が多 い、会陰部の痛みが残る症例がある、等が挙げられる。今 後、長期成績の検討が必要であるが、TURPに匹敵する 効果と低侵襲さを併せ持つ優れた手術法である。

\section{PP-227経尿道的前立腺核出術（TUEB）導入初 期 1 年間の治療経験}

\section{さいたま市立病院泌尿器科}

安水 洋太, 増田 毅, 井出 広樹

【目的】経尿道的前立腺核出術 (TUEB Transurethral Enucleation with Bipolar) は前立腺肥大症に対する、 TUR-Pや開腹手術に代わる新たな低侵襲手術である。当 施設で同手術を導入し 1 年が経過したので、その治療成績 等につき検討する。【方法】 2009 年 5 月から 2009 年 9 月 までに施行した 40 例を対象とした。【結果】平均前立腺推 定容量 $66.7 \mathrm{ml}(14-116 \mathrm{ml})$ 、平均手術時間は 126.5 分 (57

258 分)、平均核出重量 $35.7 \mathrm{~g}(9-97 \mathrm{~g})$ 、平均カテー テル留置期間 4.1 日（2－13 日）であった。術前・術後の へモグロビン值は $13.4 \mathrm{~g} / \mathrm{dl} 、 11.3 \mathrm{~g} / \mathrm{dl}$ 、術前術後の最大尿 流量率は、 $9.0 \mathrm{ml} / \mathrm{sec} 、 15.3 \mathrm{ml} / \mathrm{sec}$ であった。術後の尿道 狭窄を 6 例に認めた。半年以上経過しても継続する尿失禁 を2例認めた。【考察】TUEB は巨大前立腺肥大症に対し ても十分な切除ができ、かつ出血量も抑えることができる。 現在の標準術式である経尿道的前立腺切除術に代わり得る 術式と考えられる。一方で、術後尿失禁率・尿道狭殹率が 高い傾向にあり、改善の余地がある。

\section{PP-228 モルセレーターがない施設における TUEB の経験〜切除における注意点を含 めて}

\section{東京女子医科大学八千代医療センター泌尿器科}

天野 裕之, 矢後 尋志, 鬼塚 史朗

【目的】今回我々は新しい術式としてTUEB を経験した ためこれを報告する。【方法】当院では2008 年 3 月より TUEB を導入した。術式は標準的術式に従った。自己血 輸血は可能な症例に施行した。【成績】 27 例に対し TUEB を行った。術前 TRUS での前立腺推定重量は72.2 $(35-153 \mathrm{~g})$ これに対して平均切除重量は $26.1 \pm 12.4 \mathrm{~g}(9$ - 51g）であった。それにより最大尿流速は $4.9 \pm 4.4 \mathrm{ml} /$ $\mathrm{sec}$ から $17.8 \pm 11.1 \mathrm{ml} / \mathrm{sec}$ 、平均尿流速も $2.5 \pm 2.4 \mathrm{ml} / \mathrm{sec}$ から $9.2 \pm 6.9 \mathrm{ml} / \mathrm{sec}$ まで改善した。また残尿も $166.8 \pm$ $105 \mathrm{ml}$ であったものが術後は $48.1 \pm 52.0 \mathrm{ml}$ まで減少した。 術後において同種血輸血を行った症例は 1 例もなく、術後 腹圧性尿失禁も1例も認めなかった。【結論】TUEBの特 徵としては I 最初にEnucleationを行うため、前立腺移行 領域に分布する血管の根部での止血が可能となり、切除時 の視野がよく保たれる印象がある。2 前立腺の皮膜を早い 内から認識することが出来るため、大きな腺腫であっても 切除が安全に行うことが出来る。3核出されずに残った組 織も容易に追加切除できる。ただ剥離後の切除において 1 例止血に難渋した経験があった。剥離後の切除における注 意点も含めて報告する。 